\title{
Rhodococcus equi in the Soil Environment of Horses in Inner Mongolia, China
}

\author{
Shinji TAKAI ${ }^{1)}$, Ding ZHUANG ${ }^{2}$, Xiao-wei $\mathrm{HUO}^{3)}$, Hiroo MADARAME ${ }^{4}$, Ming-hua GAO ${ }^{5)}$, Zhong-tian TAN ${ }^{6}$, \\ Shuang-cheng $\mathrm{GAO}^{7)}$, Li-jun YAN ${ }^{8)}$, Chun-mei GUO $^{8)}$, Xue-feng ZHOU $^{8)}$, Fumiko HATORI ${ }^{1)}$, Yukako SASAKI ${ }^{1)}$, \\ Tsutomu KAKUDA ${ }^{1)}$ and Shiro TSUBAKI ${ }^{1)}$
}

\begin{abstract}
${ }^{1)}$ Department of Animal Hygiene, School of Veterinary Medicine and Animal Sciences, Kitasato University, Towada, Aomori 034-8628, Japan, ${ }^{2)}$ Department of Preventive Veterinary Medicine, College of Animal and Veterinary Science, Jilin University, Xi an Road 5333, Changchun, Jilin Province, ${ }^{3)}$ College of Animal Science and Technology, Inner Mongolia University for the Nationalities, Tongliao, Inner Mongolia 028043, Peoples Republic of China, ${ }^{4)}$ Veterinary Teaching Hospital, Azabu University, 1-17-71 Fuchinobe, Sagamiharashi, Kanagawa-ken, 229-8501 Japan, ${ }^{5}$ ZhaLanTun School of Agriculture and Animal Husbandry, Inner Mongolia 162650, ${ }^{6)}$ ManZhouLi City Veterinary Station, Inner Mongolia 021400, ${ }^{7)}$ ChenQi Veterinary Station, Inner Mongolia 021500 and ${ }^{8)}$ Wulagai Veterinary Station of Xilin Goler Meng, Inner Mongolia, Peoples Republic of China
\end{abstract}

(Received 28 November 2005/Accepted 1 March 2006)

\begin{abstract}
Little is known about the distribution of Rhodococcus equi in the soil environment of native horses in China. One hundred and eight soil samples were collected from native-horse farms in the Hulun Beier grasslands of eastern Mongolia, the Xilin Goler grasslands of southern Mongolia, and Tongliao City in Inner Mongolia, China. The isolation rates of $R$. equi from soil samples from the Hulun Beier and Xilin Goler grasslands ranged from $25.9 \%$ to $30.0 \%$. In contrast, isolation rates from soil samples from Tongliao City were as high as $82.3 \%$ and the mean number of $R$. equi in soil samples from Tongliao City was 10 times more than those of samples from the grasslands. The 488 isolates were examined using PCR for the presence of genes that encode virulence-associated $15-17 \mathrm{kDa}$ antigen protein (VapA) and the $20 \mathrm{kDa}$ antigen protein (VapB). All isolates were negative for virulence-associated proteins. Plasmid profiles of these avirulent isolates showed that cryptic plasmids of various sizes were present with an incidence of $13.3 \%$ to $21.5 \%$. The results of the present study contrast with those of our recent study (J. Vet. Med. Sci. 67:611-613, 2005), in which we reported that $R$. equi was absent from Mongolian horses in Ulaanbaatar, Mongolia. It is suggested that the difference between the results of these two studies is due to the mobile pasturing system in Mongolia and nonmobile pasturing system in Inner Mongolia.

KEY WORDS: Inner Mongolia, native horse, Rhodococcus equi.
\end{abstract}

Rhodococcus equi is one of the most important causes of pneumonia of foals at the age of one to three months $[1,2]$. $R$. equi, a soil organism, is ingested by many herbivores and has a worldwide distribution, especially in the feces and environment of horses $[1,2,13]$. The primary route of infection in foals is believed to be inhalation of virulent $R$. equi present in the foals' environment. Virulence of $R$. equi has been associated with the presence of a virulence plasmid that encodes a pathogenicity island consisting of several virulence-associated proteins (Vaps) [8]. A variety of virulence plasmids have been identified in virulent isolates throughout the world based on size and distinct restriction endonuclease digestion patterns $[4,11,12,14,16,17,20]$. There are at least 12 virulence plasmids associated with $R$. equi, and the plasmid type is related to the geographic origin of the strain [4].

Based on our molecular epidemiologic studies on virulence plasmids in Japanese native horses and horses of other breeds, we hypothesized that the transmission of the virulent form of $R$. equi and the associated virulence plasmids to Japan may have occurred through the migration of native horses from the Mongolian grasslands via China and the Korean Peninsula [12]. The presence of a $90 \mathrm{~kb}$ type-II plasmid in Korean and Japanese isolates also partially supports a common origin and ancestry of the native horses of northeast Asia [17]. More recently, we investigated soil samples and the feces of foals raised by nomadic families camped in three areas less than $100 \mathrm{~km}$ from Ulaanbaatar, Mongolia [15]. However, no R. equi was isolated from the feces of Mongolian native horses. In the present study, we focused on the soil environment of horses in Inner Mongolia, China, which is adjacent to Mongolia, to investigate the presence of virulent $R$. equi.

One hundred and eight soil samples were collected from native horse farms in the Hulun Beier grasslands of eastern Mongolia, the Xilin Goler grasslands of southern Mongolia, and Tongliao city, which is in Inner Mongolia, China (Fig. 1). Of the 108 samples, 34 were collected from farms in Hailar and 30 were collected from farms in Xin Bulag Dong, the eastern and western regions of the Hulun Beier grasslands, respectively; 27 were collected from farms in the eastern region of the Xilin Goler grasslands; 17 were collected from farms in Tongliao city. According to a field survey of local veterinarians, the disease was not recognized, as there has been no outbreak of $R$. equi infection in foals.

A small spoon was used to scrape each soil sample from the surface of the ground. Each sample was placed in a sterile tube. At the laboratory of the Department of Veterinary Medicine, Changchun University of Agriculture and Animal Sciences, $1 \mathrm{~g}$ of the soil was serially diluted with a 10 -fold volume of sterile saline. Each dilution was inoculated onto two plates of nalidixic-acid-novobiocin-actidione (cycloheximide)-potassium tellurite (NANAT) medium as described by Woolcock et al. [21]. The plates were incu- 


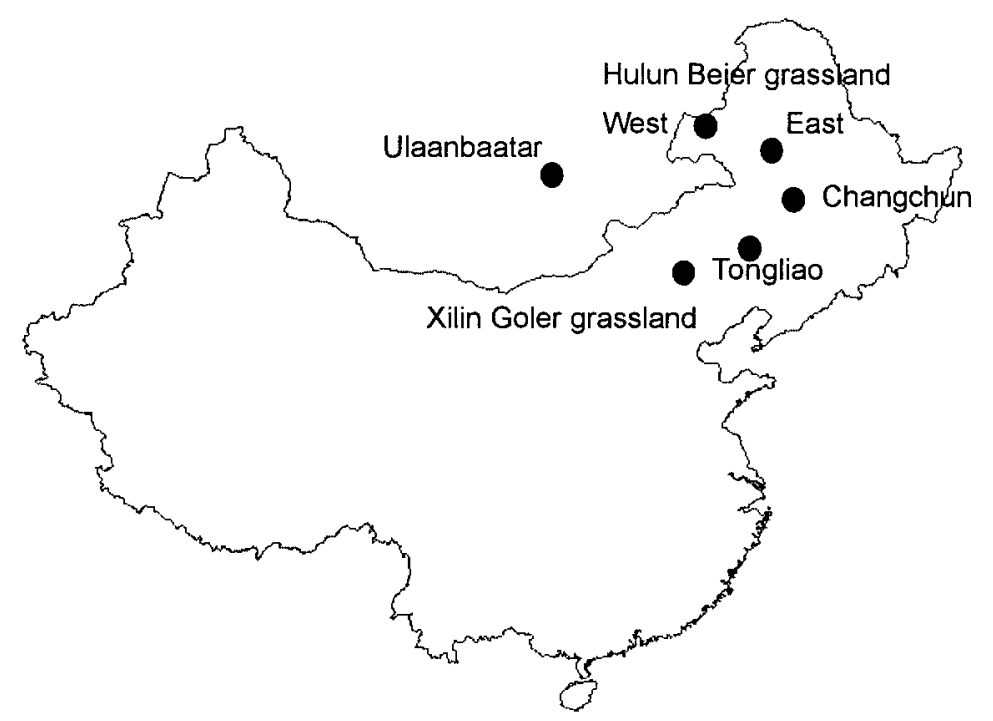

Fig. 1. Location of sites where soil samples were collected in Inner Mongolia.

bated at $30^{\circ} \mathrm{C}$ for two or three days. The $R$. equi colonies were counted, and the numbers of viable organisms per gram of feces or soil were estimated. Suspected colonies of $R$. equi were subcultured and examined for the vapA and $v a p B$ genes using the polymerase chain reaction (PCR). The target DNAs for PCR amplification were the published sequences of the 15-17 kDa antigen (VapA) gene and a 20 $\mathrm{kDa}$ antigen (VapB) gene (Genebank database accession numbers D212361 and D44469, respectively) from $R$. equi strains ATCC 33701 and 5, respectively $[6,10]$. Primer 1 (5'-GACTCTTCACAAGACGGT-3') corresponded to the sense strand at position 6-23 in the sequence of the 15-17 $\mathrm{kDa}$ antigen gene, and primer 2 (5'-TAGGCGTTGTGCCAGCTA-3') corresponded to the antisense strand at position 569-552 [6]. Primer 3 (5'-AACGTAGTCGCGGT GAGAA-3') corresponded to the sense strand at position 240-258 in the sequence of the cloned fragment containing the $20 \mathrm{kDa}$ antigen gene, and primer 4 (5'-ACCGAGACTTGAGCGACTA-3') corresponded to the antisense strand at position 1066-1048 [10]. PCR amplification was performed using previously described methods [9, 19]. Plasmid DNA was isolated from $R$. equi using the alkaline lysis method with some modifications, as described previously [20]. Samples of the plasmid preparations were separated on $0.7 \%$ agarose gels at approximately $5 \mathrm{~V} / \mathrm{cm}$ for $2 \mathrm{hr}$.

Of the Hulun Beier grassland sites, $R$. equi was isolated from five of seven farms at Hailar (isolation rates: $20-50 \%$; 25-525 colony forming units (CFU) per gram) and from three of six farms at Xin Bulag Dong (isolation rates: 40$80 \% ; 25-500 \mathrm{CFU} / \mathrm{g})$. R. equi was isolated from three of four farms at Huolinguole in the Xilin Goler grassland (isolation rates: $12.5-83.3 \% ; 50-1650 \mathrm{CFU} / \mathrm{g}$ ) and from four of four farms at Tongliao City (isolation rates: $80-100 \%$; 50$8050 \mathrm{CFU} / \mathrm{g})$. The isolation rates of $R$. equi from the grasslands of eastern Hulun Beier, western Hulun Beier, and
Xilin Goler were 29.4\%, 30.0\%, and 25.9\%, respectively (Table 1). In contrast, the isolation rate of samples from Tongliao City was as high as $82.3 \%$, and the mean number of $R$. equi in soil samples from Tongliao City was 10 times greater than those from the grasslands.

As shown in Table 2, 488 isolates were examined using PCR for presence of the genes that encode virulence-associated $15-17 \mathrm{kDa}$ antigen protein (VapA) and the $20 \mathrm{kDa}$ antigen protein (VapB), and all isolates were negative for these proteins. Plasmid profiles of the 488 isolates revealed the presence of cryptic plasmids of various sizes with an incidence of $13.3-21.5 \%$.

To test the hypothesis that the transmission to Japan of the virulent form of $R$. equi and its associated virulence plasmids may have occurred with the migration of native horses from the Mongolian grasslands via China and the Korean Peninsula, we sampled the environments of Cheju horses in Korea and Mongolian horses at Ulaanbaatar in Mongolia for isolation of $R$. equi $[12,15,17]$. Our recent study showed no evidence of $R$. equi in either fecal samples of Mongolian foals or soil samples collected from the environments in which they were held by 26 nomad families in Ulaanbaatar. Avirulent $R$. equi were isolated only from the feces of descendants of introduced Przewalski's Horses at Hustai National Park [15]. In the present study, we were able to isolate $R$. equi from soil environment of horses at the Hulun Beier and Xilin Goler grasslands of Inner Mongolia, but no virulent $R$. equi were found in those isolates. Moreover, the isolation rates and the mean number of $R$. equi from Tongliao City were significantly greater than those from the grasslands of Inner Mongolia. These data contrast with those of our recent study in which $R$. equi was absent from Mongolian horses in Ulaanbaatar, Mongolia [15].

$R$. equi is a soil saprophyte that is most commonly found in the superficial soil layer at concentrations of up to $10^{4}$ 
Table 1. Isolation of Rhodococcus equi from soil in the environments of horse breeding areas in Inner Mongolia, China

\begin{tabular}{cccccc}
\hline Area & $\begin{array}{c}\text { No. of } \\
\text { farms }\end{array}$ & $\begin{array}{c}\text { No. of } \\
\text { soil } \\
\text { samples }\end{array}$ & $\begin{array}{c}\text { No. of } \\
\text { positive } \\
\text { samples }\end{array}$ & $\begin{array}{c}\text { Isolation } \\
\text { rate (\%) }\end{array}$ & $\begin{array}{c}\text { No. bacteria } \\
\text { per g soil } \\
\text { (Mean } \pm \text { SD) }\end{array}$ \\
\hline $\begin{array}{c}\text { Eastern region of } \\
\text { Hulun Beier } \\
\text { Grasslands (Hailar) } \\
\text { Western region of } \\
\text { Hulun Beier }\end{array}$ & 7 & 34 & 10 & $29.4^{\text {a) }}$ & $135 \pm 183^{\text {c) }}$ \\
$\quad 6$ & 30 & 9 & $30.0^{\text {b) }}$ & $103 \pm 150^{\text {c) }}$ \\
$\begin{array}{c}\text { Grasslands } \\
\text { Xin Bulag Dong) }\end{array}$ & 4 & 27 & 7 & $25.9^{\text {a) }}$ & $361 \pm 588^{\text {d) }}$ \\
$\begin{array}{c}\text { Eastern region of Xilin } \\
\text { Goler Grasslands } \\
\text { (Huolinguole) }\end{array}$ & 4 & 17 & 14 & 82.3 & $1645 \pm 2190$ \\
\hline Tongliao City & 21 & 108 & 40 & 37.0 & $696 \pm 1473$ \\
\hline Total & & & & & \\
\hline
\end{tabular}

a) $P<0.01$ compared with the percentage for Tongliao City ( $\chi^{2}$ test).

b) $P<0.05$ compared with the percentage for Tongliao City $\left(\chi^{2}\right.$ test).

c) $P<0.05$ compared with the mean for Tongliao City (Student's $t$-test).

d) $P>0.05$ compared with the mean for Tongliao City (Student's $t$-test).

Table 2. Identification of virulence plasmids in isolates from Inner Mongolia

\begin{tabular}{lcccc}
\hline Area & \multirow{2}{*}{$\begin{array}{c}\text { No. of isolates } \\
\text { tested }\end{array}$} & \multicolumn{2}{c}{ PCR } & Cryptic plasmids \\
\cline { 3 - 4 } & VapA & VapB & $(\%)$ \\
\hline $\begin{array}{c}\text { Eastern region of } \\
\text { Hulun Beier } \\
\text { Grasslands }\end{array}$ & 58 & 0 & 0 & $8(13.8)^{\mathrm{a})}$ \\
$\begin{array}{c}\text { Western region of } \\
\text { Hulun Beier } \\
\text { Grasslands }\end{array}$ & 29 & 0 & 0 & $4(13.8)^{\mathrm{a})}$ \\
$\begin{array}{c}\text { Eastern region of } \\
\text { Xilin Goler } \\
\text { Grasslands }\end{array}$ & 113 & 0 & 0 & $15(13.3)^{\mathrm{a})}$ \\
Tongliao City & 288 & 0 & 0 & $62(21.5)$ \\
\hline Total & 488 & 0 & 0 & $89(18.2)$ \\
\hline
\end{tabular}

a) $P>0.05$ compared with the percentage for Tongliao City $\left(\chi^{2}\right.$ test).

CFU/gram at horse-breeding farms in Japan and many countries where $R$. equi infestation occurs every year $[1-3,7,13$, 22]. The soil concentration of $R$. equi is highest in areas where horses graze and increases with the length of time that the pasture has been grazed by horses $[3,7,22]$. Traditionally, Mongols are pastoral nomads who move with their animals in a predictable pattern according to the seasons and the availability of forage. They never camp at the exactly same place as before. With the introduction of post-Maoist economic reforms, herders no longer have customary rights to land in Inner Mongolia, China [5]. Instead, the herding families are allowed small areas of pasture called kulums (enclosures). A typical family in Inner Mongolia has a mixed herd of 75-200 sheep, 2-40 cattle, 2-60 horses and 3 Bactrian camels [5]. We speculate that the difference between the isolation of $R$. equi reported in this study and that of our previous study is related to the mobile vs. nonmo- bile pasturing practices in Mongolia and Inner Mongolia, respectively. Furthermore, the introduction of other breeds of domestic animals into the pasture may increase the number of organisms in the soil environment, as $R$. equi has been isolated from feces of domestic animals and $R$. equi infection has been described in cattle, sheep, goats, llamas, cats, and $\operatorname{dogs}[1,2]$. It is possible that the presence of populations of various species of animals at the pastures (enclosures) is sufficient to sustain and amplify $R$. equi present in the soil environment, as the animals can spread $R$. equi via their feces $[1,13]$. The greater number of $R$. equi in soil samples from Tongliao City relative to those from the grasslands may reflect the amplification in and contamination of pastures with $R$. equi by other domestic animals, especially cattle, sheep, and goats.

Cryptic plasmids were found in isolates from Inner Mongolia and the incidence was the same as that of isolates from indigenous animals or soil in Zambia [18]. The prevalence of cryptic plasmids in isolates from Tongliao City was slightly higher than those from the grasslands, but not significantly. The genetic analysis of these cryptic plasmids is now in progress.

In conclusion, avirulent $R$. equi was found in the soil environment of Inner Mongolia. Sixty years ago, the people of Inner Mongolia and their horses had the same lifestyle as the people of Mongolia currently have. The introduction of enclosures and other domestic animals might have facilitated the establishment of $R$. equi in the soil environment. Further studies are needed to investigate the ecology of $R$. equi and the presence of virulent $R$. equi in horses in other regions of Inner Mongolia and China.

ACKNOWLEDGMENTS. This study was supported by a grant-in-aid for general scientific research (Takai: $14405031,16380208)$ from the Ministry of Education, Sci- 
ence, Sports and Culture of Japan. We thank our students (N. Shimizu, M. Kawase, A. Kobayashi, Y. Gotoh, A. Takami, M. Matsuoka, A. Morita and T. Handa of Kitasato University, and Huang Hai Nan, Chang Shuang and Ri Ehi Jie of the Department of Preventive Veterinary Medicine, College of Animal and Veterinary Science, Jilin University) for their technical assistance.

\section{REFERENCES}

1. Barton, M. D. and Hughes K. L. 1980. Vet. Bull. 50: 65-80.

2. Prescott, J. F. 1991. Clin. Microbiol. Rev. 4: 20-34.

3. Prescott, J. F., Travers, M. and Yager-Johnson, J. A. 1984. Can. J. Comp. Med. 48: 10-13.

4. Ribeiro, M. G., Seki, I., Yasuoka, K., Kakuda, T., Sasaki, Y., Tsubaki, S. and Takai, S. 2005. Comp. Immunol. Microbiol. Infect. Dis. 28: 53-61.

5. Seidenberg, S. 1991. pp. 96-125. In: Nomads, ed. Peter Carmichael, Collins \& Brown, London.

6. Sekizaki, T., Takai, S., Egawa, Y., Ikeda, T., Ito, H. and Tsubaki, S. 1995. Gene 155: 135-136.

7. Takai, S. 1997. Vet. Microbiol. 56: 167-176.

8. Takai, S., Hines, S.A., Sekizaki, T., Nicholson, V. M., Alperin, D. A., Osaki, M., Takamatsu, D., Nakamura, M., Suzuki, K., Ogino, N., Kakuda, T., Dan, H. and Prescott, J. F. 2000. Infect. Immun. 68: 6840-6847.

9. Takai, S., Ikeda, T., Sasaki, Y., Watanabe, Y., Ozawa, T., Tsubaki, S. and Sekizaki, T. 1995. J. Clin. Microbiol. 33 1624-1627.

10. Takai, S., Imai, Y., Fukumaga, N., Uchida, Y., Kamisawa, K., Sasaki, Y., Tsubaki, S. and Sekizaki, T. 1995. J. Infect. Dis. 172: $1306-1311$

11. Takai, S., Murata, N., Kudo, R., Narematsu, N., Kakuda, T.,
Sasaki, Y. and Tsubaki, S. 2001. Vet. Microbiol. 82: 373-381.

12. Takai, S., Ogawa, K., Fukunaga, N., Sasaki, Y., Kakuda, T., Tsubaki, S. and Anzai, T. 2001. Comp. Immun. Microbiol. Infect. Dis. 24: 123-133.

13. Takai, S., Sasaki, Y. and Tsubaki, S. 1995. J. Equine Sci. 6: 105-119.

14. Takai, S., Sekizaki, T., Ozawa, T., Sugawara, T., Watanabe, Y. and Tsubaki, S. 1991. Infect. Immun. 59: 4056-4060.

15. Takai, S., Sengee, S., Madarame, H., Hatori, F., Yasuoka, K., Ochirel, E., Sasaki, Y., Kakuda, T., Tsubaki, S., Bandi, N. and Sodnomdarjaa, R. 2005. J. Vet. Med. Sci. 67: 611-613.

16. Takai, S., Shoda, M., Sasaki, Y., Tsubaki, S., Fortier, G., Pronost, S., Rahal, K., Becu, T., Begg, A., Browning, G., Nicholson, V. M. and Prescott, J. F. 1999. J. Clin. Microbiol. 37: 3417-3420

17. Takai, S., Son, W.-G., Lee, D.-S., Madarame, H., Seki, I., Yamatoda, N., Kimura, A., Kakuda, T., Sasaki, Y., Tsubaki, S. and Lin, Y.-K. 2003. J. Vet. Med. Sci. 65: 1313-1317.

18. Takai, S., Syakalima, M., Yasuda, J., Sasaki, Y., Tsutsumi, H., Miyagawa, E., Wada, K., Kakuda, T., Tsubaki, S. and Sugimoto, C. 2004. J. Vet. Med. Sci. 66: 743-746.

19. Takai, S., Tharavichitkul, P., Takarn, P., Khantawa, B., Tamura, M., Tsukamoto, A., Takayama, S., Yamatoda, N., Kimura, A., Sasaki, Y., Kakuda, T., Tsubaki, S., Maneekarn, N., Sirisanthana, T. and Kirikae, T. 2003. J. Infect. Dis. 188: 1717-1723.

20. Takai, S., Watanabe, Y., Ikeda, T., Tsubaki, S., Ozawa, T., Matsukura, S., Tamada, Y. and Sekizaki, T. 1993. J. Clin. Microbiol. 31: 1726-1729.

21. Woolcock, J. B., Farmer, A. M. and Mutimer, M. D. 1979. J Clin. Microbiol. 9: 640-642.

22. Woolcock, J. B., Mutimer, M. D. and Farmer, A. M. 1980. Res Vet. Sci. 28: 87-90. 